\title{
Pemanfaatan Media Online Oleh Masjid Jogokariyan Yogyakarta Dalam Membangun Komunikasi Dengan Aktivis Dakwah Tahun 2017
}

\author{
Muhammad Afnan Banu Aji, Tri Hastuti Nur Rochimah \\ Universitas Muhammadiyah Yogyakarta \\ e-mail: mafnanbanuaji@gmail.com / trihastuti.aisyiyah@gmail.com
}

\begin{abstract}
This study analyzed of management online media conducted by Yogyakarta Jogokariyan Mosque for building and fostering a communication with da'wah activists in 2017. The research method used was descriptive qualitative, and data collection techniques through interviews and document data. The results of this research that management of online media in Yogyakarta Jogokariyan Mosque does not plan regularly and systematically but is more flexible and incidental. The platform media that is most widely used to promote and build communication networks with da'wah activists is Facebook and Instagram by basing it on the intended target audience and effectiveness level. To evaluate how to use the online media of the Jogokariyan Mosque, they carried out media monitoring on the response of the audience both who followed, like, share and commented.
\end{abstract}

Keywords: Management Of Online Media, Mosque, Da'wah Activists

\begin{abstract}
Abstrak
Penelitian ini menganalisis mengenai pengelolaan media online yang dilakukan oleh Masjid Jogokariyan Yogyakarta dalam membangun dan membina sebuah komunikasi dengan Aktivis Dakwah di tahun 2017. Adapun metode penelitian yang digunakan adalah deskriptif kualitatif, dengan teknik pengumpulan data melalui metode wawancara dan data dokumen. Hasil penelitian ini menunjukan bahwa pemanfaatan media online Masjid Jogokariyan Yogyakarta tidak merencanakan secara reguler dan sistematis namun lebih fleksible. Adapun media platform yang paling banyak dimanfaatkan untuk mempromosikan dan membangun jejaring komunikasi dengan aktivis dakwah adalah Facebook dan Instagram dengan mendasarkan pada khalayak sasaran yang dituju dan tingkat efektivitas. Untuk mengevaluasi bagaimana pemanfaatan media online Masjid Jogokariyan, mereka melakukan media monitoring atas respon dari khalayak baik yang mengikuti, menyukai dan memberikan komentar.
\end{abstract}

Kata Kunci: Pemanfaatan Media Online, Masjid, Aktivis Dakwah 
Latar Belakang Masalah

Berbagai kegiatan ke-Islaman yang marak di lakukan di masjid menjadi salah satu faktor yang meramaikan kegiatan keagamaan di Indonesia. Sebagian besar kegiatan ke-Islaman berpusat di masjid, dikarenakan masjid merupakan basis terbesar umat Islam untuk terus hidup dan berkembang. Dalam komunikasi dakwah, fungsi komunikasi adalah untuk menciptakan kesadaran terhadap gagasan atau pemilik gagasan, mengubah persepsi, mengubah keyakinan, mengubah penyikap (misalnya: yang tadinya menolak jadi menerima), remainder (mengingatkan kembali), memperkuat sikap, mendapatkan respons langsung dan membangun citra (Ilaihi, 2010: 37)

Berbagai kegiatan ke-Islaman yang dilaksanakan di masjid memberikan dampak positif bagi banyak pihak. Tidak hanya pengurus masjid dan warga sekitar, namun juga para aktivis dakwah. Aktivis dakwah menjadi salah satu aktor penting dalam kegiatan-kegiatan untuk menghidupkan masjid sebagai pusat dakwah. Mengapa demikian? Karena kegiatan ke-Islaman yang dilaksanakan, masjid mampu menjadi media komunikasi terpadu untuk memenuhi kebutuhan para aktivis dakwah dalam menuntut ilmu Islam secara lebih mendalam. Di tengah perkembangan media online, belum semua masjid memperhatikan media komunikasi online untuk para jemaah yang karakteristik pola komunikasinya sudah berubah. Perkembangan media baru telah memberi peluang penggunaan metode-metode baru dalam komunikasi dakwah dengan memanfaatkan media baru. Media 
baru dianggap memliki kebaruan

yang berbeda dengan media

konvensional. Kebaruan tersebut bisa

disingkat menjadi 4C, yaitu

computing and information

technology,

communication

networks, digitalised media and

information content, dan

convergence (Flew, 2005). Dengan

demikian media baru selalu berkaitan

dengan komunikasi yang termediasi

melalui komputer, jaringan

komunikasi dan pesan yang

terdigitalisasi, yang dengan demikian

menjadikan semua pesan menjadi

konvergen. Keempat hal inilah yang

membedakan media baru dengan

media konvensional (Rahmitasari,

2017: 162).

Penelitian ini menemukan

relevansinya terkait dengan

pentingnya masjid sebagai pusat

dakwah dengan melihat konteks

perkembangan media online saat ini.
Terkait dengan topik tersebut, penelitian terdahulu tentang dakwah pernah dilakukan oleh Pardianto dengan judul "Meneguhkan Dakwah melalui New Media" yang dimuat dalam Jurnal Komunikasi Islam Vol. 03 No. 01 tahun 2013. Hasil penelitian menyimpulkan bahwa Pertama, umat Muslim harus mampu menguasai dan memanfaatkan sebesar-besarnya perkembangan teknologi informasi. Dari sisi dakwah, kekuatan internet sangat potensial untuk dimanfaatkan. Dakwah sangat penting dilakukan melalui media internet, karena selain sebagai wadah untuk menyebarkan nilai-nilai Islami (media dakwah), media internet juga dapat mempererat ikatan ukhuwah Islamiyah. Internet juga banyak kegunaan dan manfaatnya apabila kemajuan teknologi internet ini bisa digunakan dengan optimal oleh umat 
Islam. Kedua, dengan adanya membuka mata dunia akan sebuah

perkembangan globalisasi dan dunia baru, interaksi baru dan sebuah

informasi saat ini maka media jaringan mendunia yang tanpa batas.

internet menyediakan berbagai Disadari betul bahwa perkembangan

aplikasi yang bisa dijadikan tempat teknologi yang disebut internet telah

untuk menyampaikan pesan dakwah. mengubah pola interaksi masyarakat.

Sehingga kita perlu berlomba-lomba Dengan kata lain, metode tepat

menguasai teknologi informasi serta merupakan sebab diterimanya

mencari ilmu pengetahuan sebanyak- dakwah dan sarana dakwah

banyaknya, karena dengan merupakan sebab tersebar luasnya

menguasai teknologi internet akan dakwah.

dapat mewujudkan strategi yang Mengelaborasi tentang

tepat dan jitu sehingga nilai-nilai kegiatan-kegiatan dakwah Islam

Islam (pesan dakwah) dapat diterima berbasis masjid, Masjid Jogokariyan

dengan baik oleh sesama umat Islam $\quad$ Yogyakarta merupakan salah satu

dan umat-umat lain yang ingin masjid yang dijadikan rujukan. Salah

mengetahui tentang nilai-nilai Islam. satu alasannya karena Masjid

Ketiga, dengan berbagai Jogokariyan merupakan Masjid

perkembangan teknologi informasi di Percontohan Terbaik tingkat regional

era yang serba internet seperti saat Daerah Istimewa Yogyakarta (DIY)

ini, sudah saatnya meneguhkan dan tingkat nasional.

dakwah bil-internet untuk dilakukan (http://masjidjogokariyan.com/masji

oleh para pelaku dakwah $\left(d a^{\prime} i\right)$. Hal d-besar-percontohan-diyl, diakses

ini karena teknologi informasi telah pada 17 Desember 2017, Pukul 05.52 
WIB). Di tingkat nasional, Masjid Jogokariyan

Yogyakarta

mendapatkan

apresiasi dari

Kementerian Agama, yakni menjadi

Masjid Besar Percontohan Tingkat

Nasional dalam kategori idarah atau

tata

kelola

masjid

(https://www2.kemenag.go.id/berita/

435350/kemenag-beri-penghargaan-

masjid-percontohan-tingkat-nasional,

diakses pada 17 Desember 2017,

Pukul 05.48 WIB).

Penghargaan tersebut berkaitan

erat dengan beberapa langkah yang

dilakukan oleh Masjid Jogokariyan

Yogyakarta dalam membangun

komunikasi dengan para Aktivis

Dakwah. Hal tersebut dapat diamati

dari beberapa pemanfaatan media

komunikasi yang pernah digunakan

oleh Masjid Jogokariyan Yogyakarta

dalam membangun komunikasi

dengan Aktivis Dakwah tiap tahun

ke tahun. Pada era 90an, Masjid
Jogokariyan Yogyakarta memilih menggunakan media komunikasi dakwah lewat Radio Sanggar Aula FM, karena pada tahun-tahun tersebut media komunikasi berupa radio menjadi sesuatu yang sangat digandrungi oleh masyarakat luas. Berbeda lagi pada tahun 2000an di mana TV menjadi salah satu acuan masyarakat mendapatkan informasi, Masjid Jogokariyan Yogyakarta juga membuat TV Komunitas yang dinamai MJ TV sebagai sarana media komunikasi untuk menyebarkan informasi dakwah ke masyarakat dan aktivis dakwah.

Pada tahun 2017, masjid Jogokariyan Yogyakarta telah mengembangkan sarana komunikasi dengan Aktivis Dakwah sejalan dengan perkembangan teknologi informasi dengan mengembangkan media online untuk melakukan dakwah. Kegiatan-kegiatan 
dikomunikasikan

dengan

memanfaatkan media online. Paylik

(Rahmitasari，2017:164) menyebutkan

ada beberapa fungsi teknis dari media

baru, yakni: produksi (pengumpulan

informasi), distribusi (pengiriman

informasi), Display (media penampilan

informasi) dan Storage (media informasi

elektronik). Sementara itu, Lister

(2003:14) menjelaskan tentang

karakteristik dari media baru:

a. Digitality

Dalam media digital, semua data masukan diubah menjadi angka. Lalu dari data tersebut akan muncul ke dalam beragam bentuk, seperti teks tertulis, grafik dan diagram, foto, gambar bergerak yang direkam (video), dan lain sebagainya. Ini kemudian diproses dan disimpan sebagai nomor dan dapat diakses dari sumber online, disk digital, atau drive memori yang akan diterjemahkan dalam tampilan layar.

b. Interactivity

Dalam konteks ini, media baru menjadi interaktif yang ditandai dengan kemampuan user untuk ikut terlibat secara tepat dalam mengubah gambar dan teks yang mereka dapatkan. Jadi khalayak bukan lagi sebatas viewer melainkan sudah menjadi user yang tentunya menuntut masyarakat untuk menjadi aktif dengan adanya interaksi yang ada.

\section{c. Hypertext}

Hiperteks adalah karya yang terdiri dari unit materi terpisah dimana masing-masing membawa sejumlah jalur ke unit lain. Adapun sistem kerjanya dengan jaringan koneksi yang dieksplorasi oleh pengguna dengan 
menggunakan alat bantu

navigasi desain antarmuka.

d. Dispersial

Media baru telah menyebar dan lebih berkembang dalam ranah konsumsi dan produksi yang dilakukan oleh penggunanya. Akhirnya, media baru dapat dilihat sebagai media yang lebih berkembang daripada media massa, karena cara yang diakses oleh konsumen sekarang dapat lebih mudah dalam memperluas partisipasi mereka di media, baik dari interpretasi aktif hingga produksi aktual.

\section{e. Virtual}

Virtual menjadi bagian dari bahasa sehari-hari. Hal ini mengingat virtual itu sendiri mempunyai arti yang dikatakan hampir sama dengan dunia nyata. Hal ini karena media baru memiliki beberapa kecenderungan yang mirip dengan kehidupan masyarakat pada umumnya.

Beberapa kegiatan tersebut antara lain yakni, YouTube yang meng-upload beberapa kajian keIslaman yang pernah diadakan di Masjid Jogokariyan, atau live streaming beberapa kegiatan via Instagram dan Facebook, serta publikasi kegiatan melalui poster digital ke Facebook, Twitter, Instagram serta tidak kalah pentingnya juga pemberdayaan Website masjid. Konten yang dipublikasikan pun sebanding dengan jumlah pengakses media online Masjid Jogokariyan. Kondisi tersebut dapat dilihat dari tingkat akses Aktivis Dakwah melalui media online yang dimiliki oleh Masjid Jogokariyan Yogyakarta di tahun 2017; dengan data laman Facebook 
yang mencapai 120.000 pengikut dan

88.500an penyuka, Instagram yang

mencapai 47.200 follower, Twitter

yang mencapai 9.300an follower

serta Subscriber YouTube yang

mencapai 2.000an orang.

Mendasarkan pada capaian-capaian

Masjid Jogokariyan dalam mengelola

media online untuk aktivitas

dakwahnya maka penelitian ini

bertujuan untuk menganalisis

bagaimana pengelolaan media online

di Masjid Jogokariyan.

\section{Metode Penelitian}

Metode penelitian yang digunakan

adalah dekriptif kualitatif dengan

menggunakan pendekatan studi

kasus single cases. Adapun teknik

pengumpulan datanya dengan

wawancara mendalam dan

pengumpulan dokumen termasuk

dokumen-dokumen publikasi online

selama tahun 2017.

\section{Hasil Penelitian dan Pembahasan}

Secara umum untuk

mengkomunikasikan pesan-pesan

dakwah media online, pengelola

Masjid Jogokariyan tidak melakukan

perencanaan secara sistematis setiap

tahunnya. Perencanaan dilakukan

secara incidental dan menyesuaikan

dengan event-event yang ada pada

tahun 2017 tersebut. Kegiatan

dilaksanakan fleksibel sesuai dengan

kebutuhan dari Masjid Jogokaryan

dan masyarakat serta Aktivis

Dakwah yang ada (Krishna Yuniar,

Kepala Biro Humas, Media dan

Teknologi Informasi Masjid

Jogokariyan, hasil wawancara pada

19 Juli 2018).

Untuk merencanakan bagaimana mengelola media online, Masjid Jogokariyan melakukan strategic planning. Strategic planning tersebut di-upload ke 
Google Drive yang disingkronkan di

laman Website Masjid Jogokariyan.

Melalui strategic planning

Masjid Jogokariyan untuk

memakmurkan masjid serta

meninjau dari latar belakang positif

dan negatifnya, maka Tim Media

Masjid Jogokariyan juga berupaya

melakukan berbagai kegiatan atau

bentuk perencanaan yang efektif dan dapat mengundang massa untuk memakmurkan masjid. Bentuk perencanaan strategi yang telah dilakukan oleh Tim Media Masjid Jogokariyan dalam mengaplikasikan program tersebut, salah satunya adalah merencanakan timing penyebaran informasi. Hal itu dilakukan agar pesan atau konten dakwah bisa terakses dan terbaca oleh khalayak secara luas. Pembagian timing tersebut dikategorikan menjadi 4 waktu sebagai berikut;
Tabel 1

Pembagian Waktu Publikasi dan Potensi Baca Konten

Media Online Masjid Jogokariyan Tahun 2017

\begin{tabular}{cccc}
\hline Waktu & $\begin{array}{l}\text { Waktu } \\
\text { Publikasi } \\
\text { Konten }\end{array}$ & $\begin{array}{l}\text { Waktu } \\
\text { Potensi } \\
\text { Baca }\end{array}$ & $\begin{array}{l}\text { Jenis } \\
\text { Konten }\end{array}$ \\
\hline Pagi & $05.00-07.00$ & $06.00-08.00$ & Tentatif \\
Siang & $11.00-12.00$ & $12.00-13.00$ & Tentatif \\
Sore & $15.00-16.00$ & Tentatif & Tentatif \\
Malam & $20.00-21.00$ & Tentatif & Tentatif \\
\hline \multicolumn{4}{c}{ Sumber : Wawancara dengan Kepala Biro } \\
Humas, Media dan & Teknologi & Informasi \\
Masjid Jogokariyan Yogyakarta &
\end{tabular}

Berdasarkan pembagian waktu publikasi dan potensi baca konten media online di masingmasing platform media online Masjid Jogokariyan tersebut juga bisa dikatakan cukup efektif, mengingat dari setiap konten yang di-publish tersebut mampu mengundang respon yang cukup banyak dari masyarakat atau Aktivis Dakwah yang ada. Hal tersebut dapat dibuktikan dari banyaknya likers dan comments konten di masing platform yang ada; sebagai berikut :

\section{Gambar 1}


Likers dan Comments Khalayak di Media Online Masjid Jogokariyan Tahun 2017

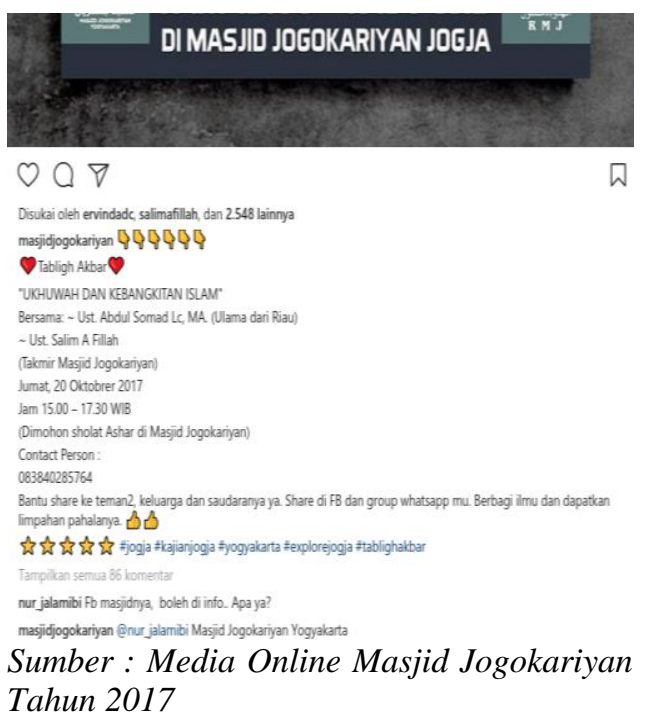

Pengelolaan media online Masjid Jogkariyan terus dikembangkan agar bisa membangun sebuah komunikasi yang efektif dan efisien dengan Aktivis Dakwah. Berikut ini adalah pengelolaan konten media Masjid Jogokariyan:

- Konten Kreatif dan Mampu Mengikuti Perkembangan

\section{Zaman}

Kreatifitas konten bisa
ditunjukan dari cara Masjid
Jogokariyan mengemas pesan,
dimana pesan dikemas dengan

design untuk menarik khalayak sasaran. Adapun creator dari design konten yang dibuat pun juga bagian dari Tim Media Masjid Jogokariyan dengan kreasi sendiri oleh Tim Media tersebut. Selain design, konten juga dikemas kreatif dengan teknik copywriting. Mengingat setiap media mempunyai kualifikasi tersendiri, seperti halnya kata-kata atau caption di Facebook dan Instagram yang bisa disamakan dan dibuat kreatif agar orang penasaran untuk membacanya. Sedangkan untuk beberapa media tertetu seperti Twitter, pesan atau katakata juga dibuat singkat padat dan jelas agar orang tidak terlalu bosan membacanya. Tim Media juga menargetkan agar di 3 detik pertama ketika orang melihat pesan tersebut tidak bosan. 
- Marketing Kegiatan melalui Media Online

Proses marketing juga menjadi hal yang penting dalam dakwah Islam Masjid Jogokariyan, karena melalui marketing inilah media Masjid Jogokariyan akan lebih mudah viral dan dikenal oleh khalayak. Salah satu content marketing yang dilakukan oleh Masjid Jogokariyan selama tahun 2017, yakni dengan memanfaatkan media online yang pada saat itu menjadi media yang banyak diakses oleh masyarakat untuk memasarkan konten dakwah masjid. Adapun platform media online yang digunakan untuk marketing kegiatan antara lain Instagram, Facebook, Twitter, YouTube maupun Website resmi yang dimiliki Masjid Jogokariyan itu sendiri
- Viral Konten Dakwah Islam

Selain memviralkan kegiatan yang dilaksanakan di masjid Jogokariyan, Tim Media masjid juga memviralkan berbagai pesan-pesan dakwah melalui media sosial yang dikelolanya. Selama tahun 2017, Masjid Jogokariyan telah mempublikasikan berbagai konten yang bermuatan dakwah Islam dengan model beragam, seperti update status, gambar, video atau artikel-artikel berwawasan Islami.

Jika dilihat dari pendekatan dakwahnya maka pendekatan yang dilakukan oleh Masjid Jogokariyan adalah pendekatan social interaction dan social integration. Pendekatan social interaction terletak pada cara Masjid Jogokariyan memanfaatkan media online 
untuk memudahkan khalayak

sasaran yang jauh bisa

mendapatkan akses untuk belajar

Islam lewat beberapa fitur yang

difungsikan oleh Masjid

Jogokariyan, seperti live

streaming, upload video di

YouTube dan masih banyak lagi.

Sementara itu pendekatan social integration, masjid Jogokariyan memanfaatkan media sebagai media untuk menciptakan masyarakat. Hal tersebut bisa dibuktikan melalui kegiatan atau konten media yang di-publish bisa menggiring banyak orang untuk datang dan mengikuti kegiatan.

- Platform Media yang Digunakan Pada tahun 2017, Facebook dan Instagram menjadi media dalam mensosialisasikan kegiatan masjid Jogokariyan. Tahun 2017, ada sebanyak 198 tema yang di-publish di Facebook Masjid Jogokariyan dan 183 tema yang di-publish di Instagram Masjid Jogokariyan. Melalui media YouTube ada sebanyak 11 tema video yang dipublish. Sementara itu di mediat Twitter, masjid Jogokariyan menampilkan sebanyak 41 tema dengan total posting 107 kali. Sedangkan melalui website http://masjidjogokariyan.com/ hanya terdapat 2 kali postingan. Terkait evaluasi dan pengawasan media online masjid jogokariyan, pengawasan dan evaluasi media online rutin dilaksanakan oleh Biro Media setiap Hari Jumat Legi, tepatnya setelah Sholat Jumat. Adapun hal yang dibahas dalam rapat tersebut secara keseluruhan, yakni perkembangan Tim Media beserta hal yang perlu dievaluasi dan ditindaklanjuti. 
Melalui monitoring ini diharapkan dapat menjadi bahan evaluasi bagi Masjid Jogokariyan sendiri dalam membangun komunikasi dengan Aktivis Dakwah yang ada dikemudian hari. Selain kegiatan monitoring dan evaluasi dari rapat yang dilaksanakan setiap Hari Jumat Legi tersebut, Tim Media Masjid Jogokariyan juga melakukan evaluasi dengan melihat fitur yang menyediakan data pengakses yang tersedia di media milik Masjid Jogokariyan.

\section{Gambar 2}

Traffic Website dan Insight Instagram Masjid Jogokariyan

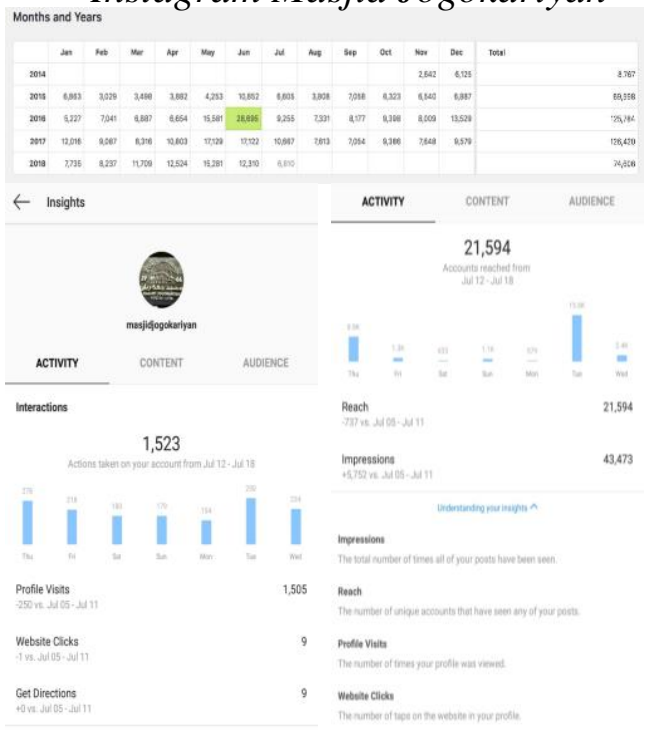

Sumber : Dokumen Admin Media Online Masjid Jogokariyan
Adapun data yang dapat

dilihat masih terbatas pada beberapa media, karena tidak semua media yang digunakan oleh Masjid Jogokariyan menyediakan fitur untuk melakukan pemantauan. Walaupun beberapa media belum menyediakan fitur untuk monitoring, tim media Masjid Jogokariyan tetap melakukan pengawasan dan evaluasi dengan melihat jumlah followers, likers, comments atau subscribers di masing-masing media yang ada.

\section{Penutup}

Masjid Jogokariyan sebagai salah satu pusat dakwah telah mengelola media online dikarenakan perubahan perilaku khalayak yang sudah memanfaatkan media online untuk mengakses informasi termasuk informasi dakwah. Masjid Jogokariyan memiliki Biro Humas, Media dan Teknologi Informasi untuk mengelola komunikasi. 
Meskipun dalam perencanaan masih

belum sistematis dan incidental

namun sebagai sebuah organisasi

dengan pendanaan mandiri dan

mengandalkan dana publik,

pengelolaan media online nya dapat

menjadi rujukan bagi masjid-masjid

yang lain.

Pengelolaan pesan lebih banyak difokuskan dengan menggunakan platform media yaitu Facebook dan Instagram dengan mendasarkan pada pertimbangan khalayak sasaran. Berdasarkan pada data tahun sebelumnya bahwa penggunaan kedua media tersebut mempunyai feedback yang cukup besar, dilihat dari yang menyukai, memberi comments dan membagikan konten. Meskipun media-media lain juga digunakan seperti Website, Twitter maupun YouTube. Untuk melakukan monitoring dan evaluasi, dilakukan dalam rapat setiap Jumat
Legi dan menggunakan analisis comments, likes dan followers di masing-masing platform media.

$$
\text { Adapun faktor pendukung }
$$

kegiatan pemanfaatan media online dalam membangun komunikasi di Masjid Jogokariyan tersebut terletak pada meleknya pihak takmir terhadap teknologi, pesatnya perkembangan teknologi informasi dan komunikasi, fasilitas yang sangat mendukung dakwah via media online serta adanya media partner yang selalu support kegiatan dakwah; dan faktor penghambatnya yang terletak pada seringnya server penuh karena banyak pengakses dan peralatan media yang kurang portable untuk live streaming di media online milik Masjid Jogokariyan.

\section{Daftar Pustaka}

Ilaihi, Wahyu. (2010). Komunikasi Dakwah. Bandung: Remaja Rosdakarya. 
Junaedi, Fajar. (2014). Manajemen Media Massa Teori, Aplikasi, dan Riset. Yogyakarta: Buku Litera.

Kurnia, N. (2005). Perkembangan Teknologi Komunikasi dan Media Baru: Implikasi terhadap Teori Komunikasi. Jurnal Komunikasi MediaTor, 06(02), 291-296.

Lister, M., Dovey, J., Gidding, S., Grant, I., \& Kelly, K. (2003). New Media: A Critical Introduction. New York: Routledge.

Pardianto. (2013). Meneguhkan Dakwah Melalui New Media. Jurnal Komunikasi Islam. 03(01), 22-47.

Rahmitasari, Diyah Hayu (ed.). (2017). Manajemen Media di Indoensia. Jakarta: Yayasan Pustaka Obor Indonesia.

Tahir, Qaharuddin, Hafied Cangar dan Basir Syam. (2014). Masjid Kampus Sebagai Media Komunikasi Aktivis Dakwah dalam Pembentukan Karakter Mahasiswa. Jurnal Komunikasi KAREBA. 03(03), 186-192.

Tasmara, Toto. (1997). Komunikasi Dakwah. Jakarta: Gaya Jaya Pratama Jakarta.

\section{Sumber Lain}

Admin Masjid Jogokariyan. (2016). Kemenag Jogja: Masjid Jogokariyan Jadi Juara Lomba Masjid Besar Percontohan DIY. Diakses pada 01 September 2017 dari http://masjidjogokariyan.com/mas jid-besar-percontohan-diy/.
Admin Masjid Jogokariyan. (2011). Profil Masjid Jogokariyan. Diakses pada 15 Mei 2018 dari https://masjidjogokariyan.com/ab out/.

Arif. (2016). Kemenag Beri Penghargaan Masjid Percontohan Tingkat Nasional. Diakses pada 13 Desember 2017 dari

https://www2.kemenag.go.id/berit a/435350/kemenag-beripenghargaan-masjid-percontohantingkat-nasional. 